\title{
Coupling of Realistic Rate Estimates with Genomics for Assessing Contaminant Attenuation and Long-Term Plume Containment
}

Principal Investigator:

F. S. Colwell

Biological Sciences

Idaho National Laboratory

P.O. Box 1625

Idaho Falls, ID 83415-2203

Phone: 208-526-0097

FAX: 208-526-0828

e-mail: Frederick.colwell@inl.gov

Co-Investigators:

R. L. Crawford

R. Starr

Department of Bacteriology and Biochemistry

North Wind, Inc.

University of Idaho

P.O. Box 51174

Moscow, ID 83843

1425 Higham St.

Phone: 208-885-6580

Idaho Falls, ID 83405

FAX: 208-885-5741

Phone: 208-557-7820

e-mail: crawford@uidaho.edu

e-mail: bstarr@nwindenv.com

Project Personnel: Mark Delwiche and Deborah Newby (INL), Dan Erwin and Janice Strap

(Univ. of Idaho)

Project Number: 86805

INL Grant Number: DE-AC07-76IDO1570

University of Idaho Grant Number: DE-FG07-02ER63500

North Wind Grant Number: DE-FG07-02ER63510

Project Duration: September 2002 through September 2005

\section{Research Objective}

Acceptance of monitored natural attenuation (MNA) as a preferred treatment technology saves significant site restoration costs for DOE. However, in order to be accepted MNA requires direct evidence of which processes are responsible for the contaminant loss and also the rates of the contaminant loss. Our proposal aims to: 1) provide evidence for one example of MNA, namely the disappearance of the dissolved trichloroethylene (TCE) from the Snake River Plain aquifer (SRPA) at the Idaho National Laboratory's Test Area North (TAN) site, 2) determine the rates at which aquifer microbes can cometabolize TCE, and 3) determine whether there are other examples of natural attenuation of chlorinated solvents occurring at DOE sites. To this end, our research has several objectives. First, we have conducted studies to characterize the microbial processes that are likely responsible for the co-metabolic destruction of TCE in the aquifer at TAN (University of Idaho and INL). Second, we are investigating realistic rates of TCE co-metabolism at the low catabolic activities typical of microorganisms existing under aquifer conditions (INL). Using the co-metabolism rate parameters derived in low-growth bioreactors, we will complete the models that predict the time until background levels of TCE are attained in the aquifer at TAN and validate the long-term stewardship of this plume. Coupled with the research on low catabolic activities of co-metabolic microbes we are determining the patterns of functional gene expression by these cells, patterns that may be used to diagnose the co-metabolic activity in the SRPA or other aquifers. Third, we have systematically considered the aquifer contaminants at different locations in plumes at 
other DOE sites in order to determine whether MNA is a broadly applicable remediation strategy for chlorinated hydrocarbons (North Wind Inc.). Realistic terms for co-metabolism of TCE will provide marked improvements in DOE's ability to predict and monitor natural attenuation of chlorinated organics, increase the acceptability of this solution, and provide significant economic and health benefits through this noninvasive remediation strategy. This project also aims to derive valuable genomic information about the functional attributes of subsurface microbial communities upon which DOE must depend to resolve some of its most difficult contamination issues.

\section{Research Progress and Implications}

TCE contamination of groundwater is a serious environmental concern at the TAN site where a TCE plume contaminates the fractured basalt that underlies the site. The concentration of dissolved TCE at the site is decreasing by natural attenuation and this has a highly significant, positive economic impact for site remediation. Our work performed to date is allowing the research team as a whole to make conclusions regarding the capability of microbial communities in the aquifer to adapt to the presence of TCE within TAN site groundwater and to scientifically validate the capacity of these populations to promote TCE co-metabolism and thereby foster significant rates of bioremediation (natural attenuation) within the TCE plume.

Presence of known TCE co-metabolizers, eubacteria, archaea, and eukarya in the Snake River Plain Aquifer. In order to determine how SRPA microbial communities contribute to the natural attenuation at TAN, we conducted a survey of eubacteria, archaea, and eukarya therein. Within the eubacterial group we selectively searched for cells known to possess the ability to co-metabolize TCE. For each of these groups, planktonic communities were collected from the SRPA by concentrating the cells present in $>13,000 \mathrm{~L}$ of aquifer water using hollow fiber filtration (1). Attached cells were collected from basalt substrates that were allowed to colonize in the aquifer for several months prior to retrieval (1). For each of these respective groups, total DNA extracted from the collected cells was used as template for $16 \mathrm{~S}$ rDNA (or 18S rDNA) amplification. The resultant amplicons were cloned and picked into 96 well format plates. Plasmid isolations were performed using robotic equipment within the INL/University of Idaho Molecular Ecology \& Genomics Laboratory (MEGL). Restriction enzyme digests of the purified plasmid DNA were analyzed by agarose gel electrophoresis. Clones were grouped according to their restriction patterns and amplicons from representative clones from each group were sequenced. To investigate the microbes known to specifically conduct TCE co-metabolism we also searched for the presence of functional genes known to either identify these cell types or to be involved on TCE cometabolism.

Oxygenases such as methane monooxygenase (MMO) and ammonia monooxygenase (AMO) are well known for their abilities to co-oxidize and thereby degrade TCE and so several of our investigations involved the characterization of these communities within the SRPA. In a preliminary study, native methanotrophs from SRPA waters were studied to determine the genetic potential for TCE co-metabolism in the aquifer. Sequences were identified through phylogenetic analysis of $16 \mathrm{~S}$ rRNA and MMO genes retrieved from several wells in the SRPA (6). Type I methanotroph clones aligned with Methylomonas, Methylocaldum, and Methylobacter sequences and a distinct phylogenetic lineage grouped near Methylobacter. The majority of clone sequences in type II methanotroph 16S rRNA, pmoA, and mmoX libraries grouped closely with sequences in the Methylocystis genus. A subset of the type II methanotroph clones from the aquifer had sequences that aligned closely to Methylosinus trichosporium OB3b and Methylocystis spp., known TCE-cometabolizing methanotrophs. In a separate study, we used primers specific for conserved regions of the pmoA gene of the particulate form of MMO (pMMO), the mmoX gene of the soluble form of MMO (sMMO), and the amoA gene of AMO to assess the presence of these genes in attached and planktonic communities in the aquifer. We used polymerase chain reaction (PCR) to attempt amplification of these genes from whole community (metagenomic) DNA obtained directly 
from the aquifer (1). Based on these functional gene analyses, bacteria related to the type II methanotroph Methylocystis dominated both free-living and attached SRPA communities. Type I sequences which grouped nearest to Methylobacter and Methylomonas, were only obtained from the free-living community. Sequences similar to the amoA gene associated with ammonia oxidizing bacteria (AOB) most closely matched a sequence from the uncultured bacterium BS870 but showed no substantial alignment to known, cultured AOB. Together these studies detected numerous sMMO-like gene sequences previously associated with high rates of TCE co-metabolism in both the free-living and the attached communities thus suggesting the metabolic potential of the indigenous populations to carry out natural attenuation. The sequence data derived from these studies also will allow the development of primers or fluorescent in situ hybridization (FISH) probes that are specific to the methanotrophs present in the aquifer.

Because eubacteria other than methanotrophs and ammonia oxidizers are known to be cometabolizers of TCE, we also characterized subsurface eubacterial populations. The subsurface microbial populations of the planktonic and attached communities were found to be different, with the biofilm community displaying a higher level of eubacterial diversity than the planktonic population (16). Overall, the microbial community present in the SRPA contained many previously undescribed and uncultured bacteria as well as new species in known genera such as Arthrobacter, Janthinobacterium, Sphingomonas, Afipia, Caulobacter, Methylobacillus and Pseudomonas. Some of these genera are known to contain representatives that degrade TCE. The identification of the microorganisms in the SRPA aids the elucidation of the role that intrinsic bioremediation (natural attenuation) plays when chlorinated compounds contaminate basalt aquifers.

Eukaryotic organisms may also play roles in natural attenuation of contaminants such as TCE through the activities of non-specific oxygenases such as cytochrome P450 and also through the grazing of prokaryotes that are engaged in TCE co-metabolism. However, little is known about eukaryotic diversity in groundwater and the potential for contribution of eukaryotes to the degradation of anthropogenic contaminants such as TCE in these systems should not be ignored. The eukarya community present in the SRPA aquifer contained many previously undescribed and uncultured eukaryotes as well as new species in known genera such as Exophiala, Anurofeca, Paraphaeosphaeria, and Lacustromyces (15). By identifying the eukarya in the SRPA we can aid the elucidation of the roles that eukarya play in intrinsic bioremediation when chlorinated solvents contaminate deep basalt aquifers. In addition, this work is contributing to the knowledge base of eukaryote diversity in the Earth's subsurface.

With respect to archaeal diversity in the SRPA, the planktonic and biofilm communities comprised many previously undescribed and uncultured archaea. The sampled planktonic and biofilm archaeal communities were different at the genetic level (FST $=0.05922, \mathrm{p}<0.0001)$. The heterologous coverage of the planktonic library by the biofilm library was not significantly different $(p=0.168)$ from the homologous coverage of the planktonic library to itself indicating most sequences from the planktonic library had high similarity to sequences in the biofilm library (14). The heterologous coverage of the biofilm library to the planktonic library was significantly different $(p=0.044)$ from the homologous coverage of the biofilm library. This indicated that some sequences in the biofilm library had no close relatives in the planktonic library. The nucleotide diversity and total genetic variation was lower for the biofilm library. This was consistent with the limited phylogenetic distances observed among biofilm clones compared with the planktonic library. With the exception of one biofilm clone, all archaeal clones in this study were found to be Crenarchaeota. This is a surprising result given that the methane in the aquifer appears to be biogenic (6) and likely produced by members of the Euryarchaeota. One of our prior studies surveyed archaeal diversity in several wells from the SRPA and found evidence of abundant Euryarchaeota (8). The identification of the archaea in the SRPA aids the elucidation of the roles that 
archaea play in intrinsic bioremediation when chlorinated solvents contaminate deep basalt aquifers. In addition, this work contributes to the knowledge base of archaeal diversity in the Earth's subsurface.

Evidence of biogenic methane in the aquifer to sustain TCE co-metabolism. From our investigations of different wells in the SRPA, we determined that methane concentrations in the groundwater ranges from 1 to $>1000 \mathrm{nM}$ (6). Continuous Flow-Isotope Ratio Mass Spectrometry was used to measure the ${ }^{13} \mathrm{C} /{ }^{12} \mathrm{C}$ of dissolved methane $\left(\delta^{13} \mathrm{CH}_{4}\right)$ and carbon dioxide $\left(\delta^{13} \mathrm{CO}_{2}\right)$ in the aquifer. Our findings suggest that the methane is oxidized by methanotrophs, thus providing evidence that these cells can be sustained by their primary substrate. Another important observation was that the methane itself is formed through $\mathrm{CO}_{2}$ reduction by methanogens.

Although we have not yet determined where these methanogens reside in the aquifer, it appears that a C-1 cycling consortium of microbes (methanotrophs and methanogens) exists therein and that this consortium may fortuitously be involved in the co-metabolism of TCE.

Determination of methane oxidation rates by starved methanotrophs. A premise of subsurface microbiology is that cells in the subsurface are typically severely limited in terms of energy supply and therefore exhibit low activities (9). Given that condition we believe that cells in the SRPA that may be wholly or partially responsible for the co-metabolism of TCE are doing so under survival conditions. In order to simulate these conditions in the lab we have grown a model methanotroph (Methylosinus trichosporium OB3b) in a biomass recycle reactor (BRR) that is designed to starve the cells for methane. We conducted experiments to investigate the activities of these cells under different methane and TCE concentrations and we also preserved DNA and RNA extracted from the cells when they are sustained at logarithmic growth and under starvation conditions. Preservation of these nucleic acids will permit us to conduct real time PCR to confirm methanotroph numbers in the reactor and also for gene expression studies under the two different conditions.

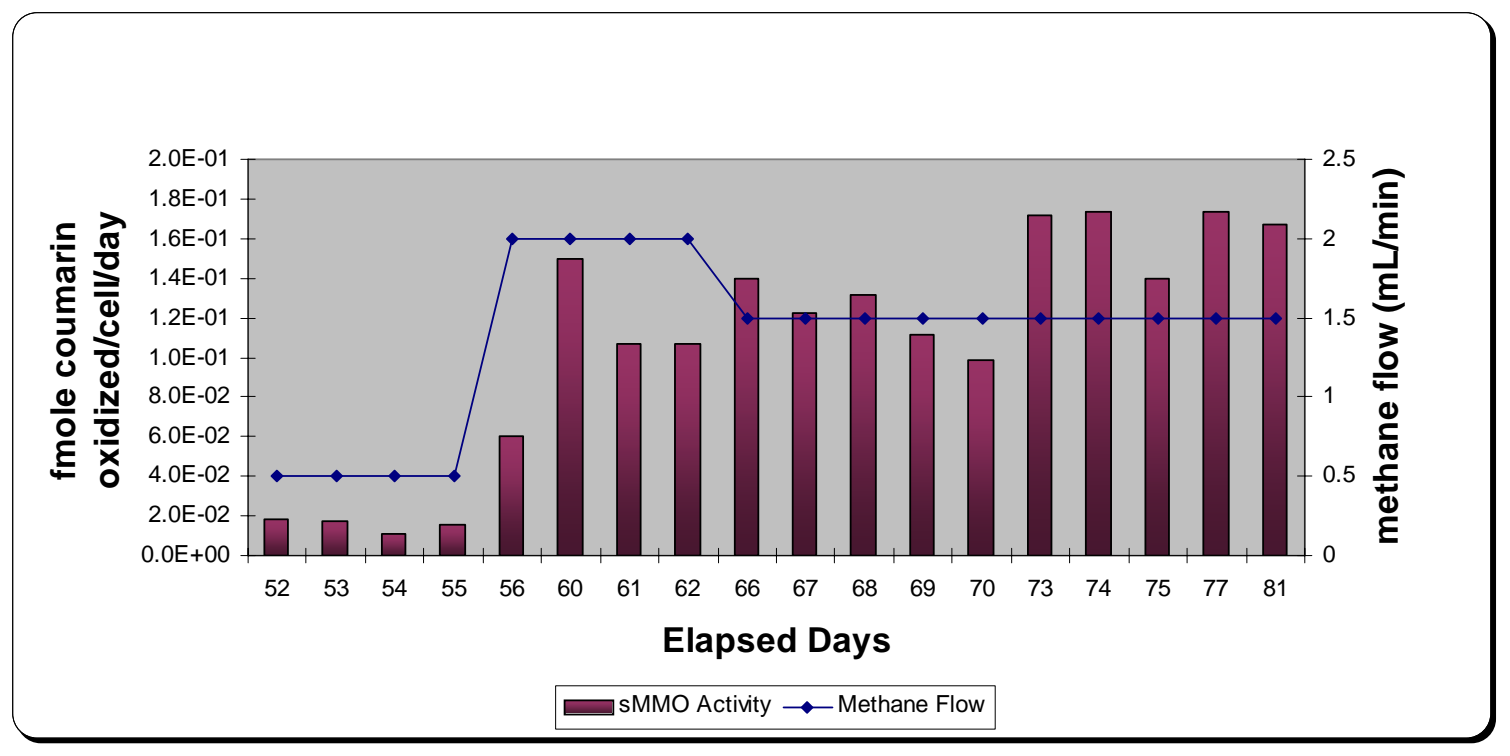

Figure 1. Relationship of sMMO activity (coumarin oxidation rate) to methane feed rate for $M$. trichosporium OB3b cells grown in a BRR. Total gas feed was the methane rate shown plus 50 $\mathrm{ml} / \mathrm{min}$ air. 
When sustained in a BRR, OB3b cells respond slowly to changes in availability of methane based on the rate of coumarin oxidation as a surrogate for methane oxidation (5) (Figure 1). With stable methane concentrations the coumarin oxidation rates of the cells remained constant. If methane supply was interrupted for a prolonged period (several hours to several days), the ability to oxidize coumarin dropped to zero. When methane feed was re-established, coumarin oxidation rates gradually recovered. For BRR-sustained cells, coumarin oxidation was not detectable when dissolved methane concentration was below $2 \mathrm{nM}$. Excess methane $(>1 \%$ in feed) did not result in any change to the coumarin oxidation rate.

Figure 2. sMMO

activity and TCE concentrati ons for $M$. trichospori um OB3b cultures from the BRR when the cells are either exposed and not exposed to TCE.

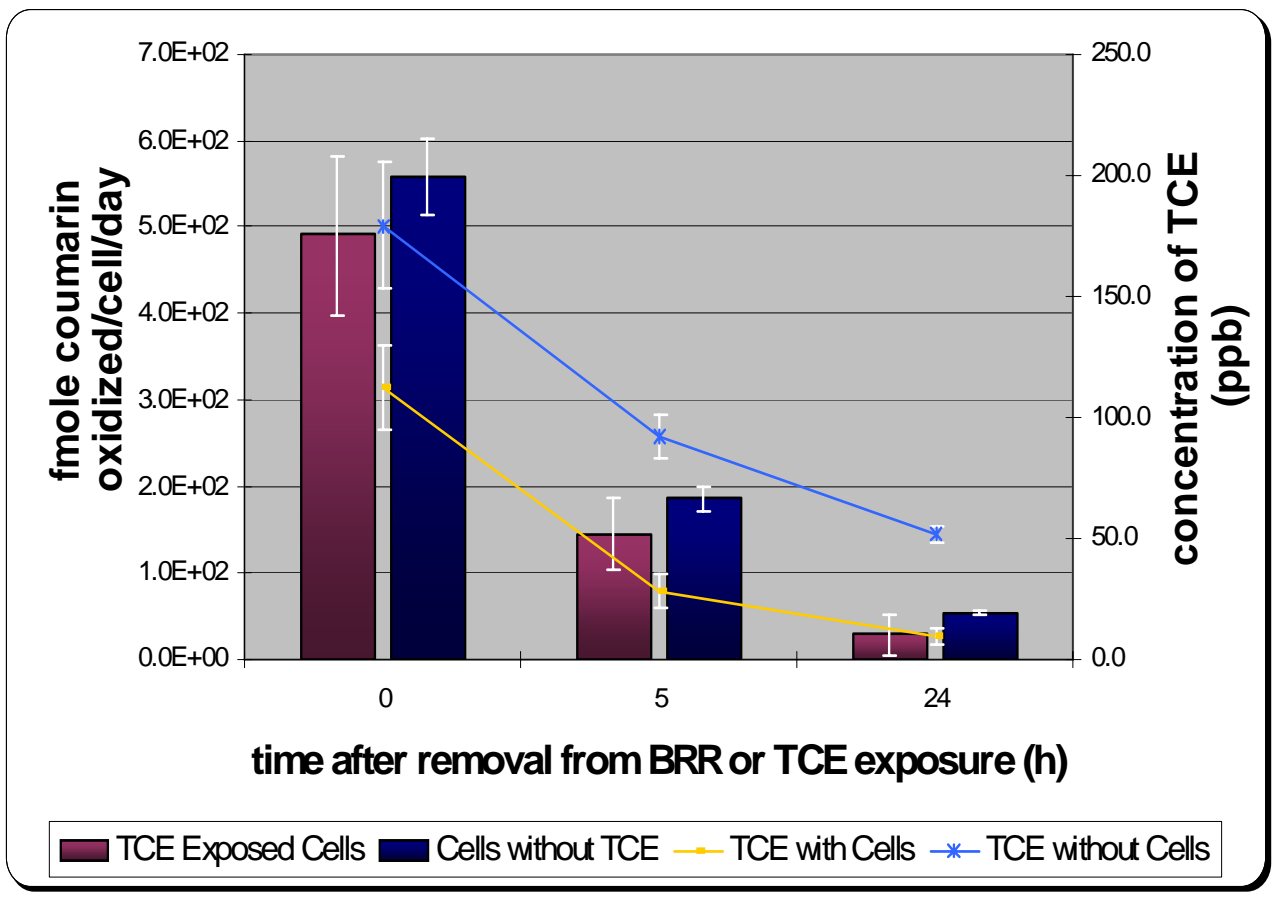

found TCE

\section{We}

to be transformed by BRR-sustained OB3b cells (Figure 2). TCE disappeared from the headspace of these cultures more rapidly than it did from abiotic controls although loss of TCE also occurs in vials without cells. OB3b cells from the BRR held for 5 and $24 \mathrm{~h}$ showed a gradual decrease in sMMO activity regardless of whether TCE was present or not suggesting that cells in this state are not adversely affected by the presence of TCE at these concentrations.

Presence of starvation/survival genes in Methylosinus trichosporium OB3b. We are also studying gene expression in methanotrophs as a result of their starvation in the BRR and their exposure to TCE. In order to do this we have identified several putative starvation/stress genes that may be expressed by OB3b (Table 1). Eight gene sequences (noted in Table 1) coding for proteins related to housekeeping, cell stress, and key metabolic activities were retrieved from databases with data on phylogenetic relatives of OB3b in the taxa $\alpha$-proteobacteria. Oligonucleotide probes (50-60 bp) for a microarray need to be specific, but analysis of the sequence alignment of these genes showed low sequence conservation, so probes designed from consensus sequences were highly degenerate. Therefore, OB3b-specific sequences for the eight genes needed to be determined. First, primers (18-22 bp) were designed from shorter regions that were conserved in the consensus sequences. The amplicons are in the process of being cloned and sequenced. OB3b specific oligonucleotides will subsequently be synthesized from this sequence information, and added to a microarray that includes sequences of structural and regulatory gene 
sequences for $\mathrm{mmo}$ and $\mathrm{pmo}$ targets for later analysis of gene expression under different nutrient availability conditions and in the presence and absence of TCE.

Table 1. Candidate methanotroph genes for a microarray that would permit the evaluation of genes expressed under different conditions. Shown are the genes of interest, the function of the gene product, and conditions of expected expression. We are in the process of cloning and sequencing the $M$. trichosporimum OB3b genes shown in bold.

\begin{tabular}{|c|c|c|c|c|c|}
\hline \multirow[b]{2}{*}{ Gene } & \multirow[b]{2}{*}{ Function or product } & \multicolumn{2}{|c|}{ Expected expression during: } & \multirow[b]{2}{*}{$\begin{array}{l}\text { stress, stasis; } \\
\text { TCE injury }\end{array}$} & \multirow[b]{2}{*}{ Reference } \\
\hline & & $\begin{array}{l}\text { active } \\
\text { growth; } \\
\text { reproduction }\end{array}$ & $\begin{array}{l}\text { survival; } \\
\text { maintenance }\end{array}$ & & \\
\hline $16 S$ & ribosome assembly & + & $+/-$ & $+/-?$ & \\
\hline $\begin{array}{l}\text { mmoX } \\
\text { etc. }\end{array}$ & methane metabolism (sMMO) & + & $-?$ & $+?$ & (11) \\
\hline pmoСAB & methane metabolism (pMMO) & + & $-?$ & $+?$ & $(2,11)$ \\
\hline Gene? & $\begin{array}{l}\sigma^{70} \text {, growth, reproduction in } \\
\text { OB3b; housekeeping }\end{array}$ & + & - & - & $\begin{array}{l}\text { (11), } \\
\text { references } \\
\text { therein; } \\
\text { (3) }\end{array}$ \\
\hline$m m o D$ & Assembly of sMMO? & + & - & $+?$ & $(11)$ \\
\hline$m m o G$ & $\begin{array}{l}\text { Required for sMMO } \\
\text { transcription, activity }\end{array}$ & + & - & $+?$ & (11) \\
\hline rpoN & $\begin{array}{l}\text { Encodes } \sigma^{\mathrm{N}}\left(\sigma^{\mathrm{N}} \text { plays a role in }\right. \\
\text { both } \mathrm{C} \text { and } \mathrm{N} \text { metabolism) }\end{array}$ & + & - & $+?$ & (11) \\
\hline ntrA & $\begin{array}{l}\text { Encodes } \sigma^{54} \text {; controls } m m o X \\
\text { expression }\end{array}$ & + & - & $+?$ & $(3,7)$ \\
\hline nifH & $\begin{array}{l}\text { Nitrogenase genes; high energy } \\
\text { drain; controlled by same } \\
\text { promoter as sMMO genes }\end{array}$ & + & - & - & (3) \\
\hline$m x a F$ & $\begin{array}{l}\text { Active site for } \mathrm{MeOH} \\
\text { dehydrogenase }\left(2^{\text {nd }} \text { enzyme in }\right. \\
\text { methanotroph catabolic } \\
\text { pathway) }\end{array}$ & + & - & $+?$ & $\begin{array}{l}\text { (3), } \\
\text { references } \\
\text { therein }\end{array}$ \\
\hline rpoS & $\begin{array}{l}\text { encodes } \sigma^{\text {s? }} \text { subunit of RNA } \\
\text { polymerase }\end{array}$ & - & + & $+?$ & \\
\hline relA & Amino acid restriction & - & $+?$ & + & \\
\hline spoT & $\begin{array}{l}\text { Starvation protein, caloric } \\
\text { restriction }\end{array}$ & - & $+?$ & + & \\
\hline uspA & $\begin{array}{l}\text { Universal stress protein } \\
\text { (UspA); ancient, conserved } \\
\text { proteins in bacteria, archaea }\end{array}$ & $-?$ & $+?$ & + & (4) \\
\hline groEL & Heat-shock protein & - & - & + & $(18)$ \\
\hline groES & Heat-shock protein & - & - & + & $(18)$ \\
\hline tuf & $\begin{array}{l}\text { Encodes elongation factor Tu; } \\
\text { housekeeping gene }\end{array}$ & + & & & (18) \\
\hline
\end{tabular}


Representative stress genes proved to have enough sequence conservation across members of the $\alpha$-proteobacteria to allow the design of primers. When PCR was conducted with DNA extracted from OB3b, these primers enabled successful amplification of bands that were of appropriate size (except for the tuf gene) to match the targeted gene sequences (Figure 3). All eight primer sets for the genes of interest resulted in amplification of products of the expected size.

Figure 3: Five of the eight genes amplified from DNA extracted from $M$. trichosporium OB3b by using newly designed primers.

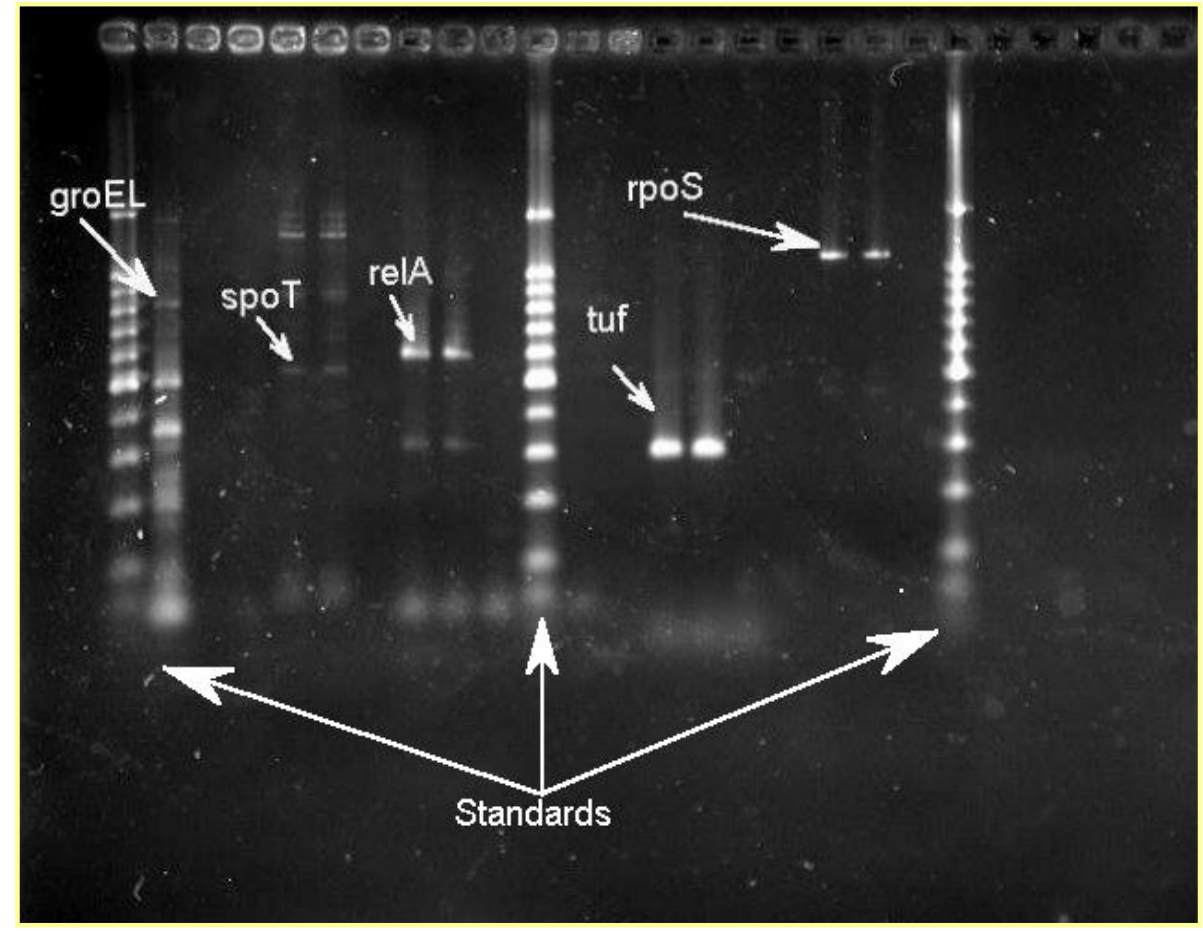

Conceptual and mathematical models for natural attenuation at TAN and consideration of MNA at other DOE sites. The selection of MNA as part of the CERCLA remedy at TAN prompted us to investigate TCE co-metabolism at other DOE facilities. We applied the "tracer corrected" method (10) to determine if TCE was preferentially attenuated relative to a conservative co-contaminant in aerobic groundwater. Over one hundred TCE plumes at 24 DOE sites were studied to identify those with the appropriate combination of features (oxic conditions, minimum plume length, appropriately located monitoring wells, presence of a conservative cocontaminant to TCE) needed to apply the tracer corrected method (13). Examples where TCE natural attenuation appears to occur include the Northwest Plume at the Paducah Gaseous Diffusion Plant and in the M-Area Aquifer at the Savannah River Site. In both of these locations it appears that TCE is preferentially attenuated under aerobic conditions, presumably by cometabolism. For example, at Paducah we found a unique decline in TCE concentrations relative to ${ }^{99} \mathrm{Tc}$ (depicted in a plot of Ln (TCE/Tc)) in the Lower Regional Aquifer at a point 11,000 ft from the origin of the plume (Figure 4). These preliminary data require additional substantiation; however, there is also evidence based on stable chlorine isotopes that natural attenuation of TCE is occurring at the Paducah site (17). In all, we found that nine plumes at four DOE sites were amenable to this evaluation and that preferential attenuation of TCE appears to occur in eight of the nine plumes (12). Such a high fraction of positive results for appropriate plumes suggests that preferential attenuation of TCE is a common process in aerobic groundwater. 


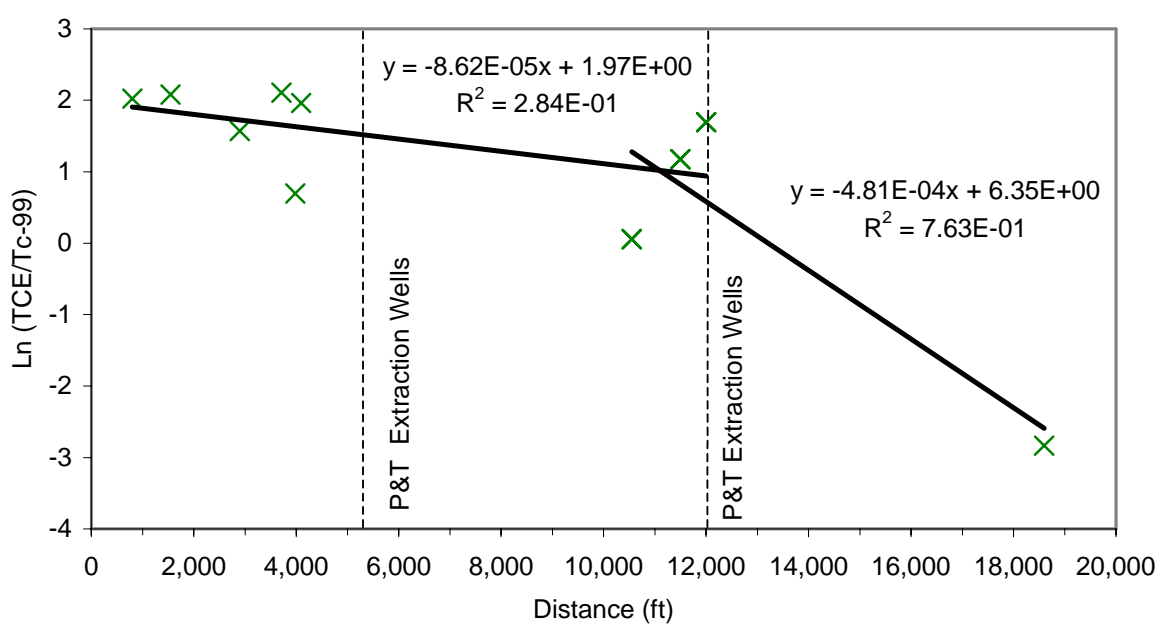

Figure 4. Ln (TCE: ${ }^{99} \mathrm{Tc}$ ) in the Lower Regional Aquifer, Paducah NW plume.

\section{Planned Activities}

In the coming months we plan to complete aspects of the research described above as follows:

- Derive kinetic rates for a starved methanotroph using methane and cometabolizing TCE.

- Convert these kinetic rates to terms used for reaction path modeling of the TCE plume at TAN to understand the fraction of natural attenuation contributed by methanotrophs.

- Clone and sequence putative starvation and stress genes from M. trichosporium OB3b to confirm that the sequences are related to genes that code for proteins known to be expressed under conditions of cell stress.

- Once confirmed, these sequences will be used to complete an existing methanotroph microarray by adding the oligonucleotides that represent these starvation and stress genes. The modified microarray will be used to discover gene function under different metabolic conditions, in our case, starved cells, or cells in the presence of TCE. In anticipation of development of these microarrays, cells from the BRR, with and without TCE exposure, have been preserved for extraction of RNA for reverse transcriptase PCR.

- Using the completed microarray, evaluate gene products from M. trichosporium OB3b that has been grown under different conditions (e.g., logarithmic vs. static growth, in the presence vs. in the absence of TCE).

\section{Information Access}

\section{Optional Additional Information}

The following publications and presentations were partially or completely achieved through this funding:

- $\quad$ Newby, D. T., D. W. Reed, L. M. Petzke, A. L. Igoe, M. E. Delwiche, F. F. Roberto, J. P. McKinley, M. J. Whiticar, and F. S. Colwell. 2004. Diversity of methanotroph communities in a basalt aquifer. FEMS Microbiol. Ecol. 48:333-344.

- Lehman, R. M., S. P. O'Connell, A. Banta, J. K. Fredrickson, A.-L. Reysenbach, T. L. Kieft, and F. S. Colwell. 2004. Microbiological comparison of core and groundwater samples collected from a fractured basalt aquifer with that of dialysis chambers incubated in situ. Geomicrobiol. J. 21:169-182.

- Erwin, D.P. 2004. Molecular Characterization of Methanotroph Communities within the Eastern Snake River Plain Aquifer. Master of Science, Microbiology, Molecular Biology and Biochemistry, University of Idaho. 
- $\quad$ Erwin, D. P., I. K. Erickson, M. E. Delwiche, F. S. Colwell, J. L. Strap, and R. L. Crawford. 2005. Diversity of oxygenase genes from methane- and ammonia-oxidizing bacteria in the Eastern Snake River Plain aquifer. Appl. Environ. Microbiol. 71:2016-2025

- Strap, J.L., F.S. Colwell, R.L. Crawford. Eukaryotic diversity in planktonic and biofilm populations of the Snake River Plain aquifer. Appl. Environ. Microbiol. In review.

- Lehman, R.M., D.E. Cummings, M.E. Downing, F.S. Colwell, and W.K. Keener. Transition of aquifer microbial communities with the implementation of lactate-enhanced bioremediation of trichloroethene in a deep, fractured basalt aquifer. Environ. Microbiol. In review.

- $\quad$ Lee, M.H., W.K. Keener, R. Wymore, A. Miller, F. Colwell, K.S. Sorenson, and M.E. Watwood. Intrinsic aerobic TCE cometabolism by methanotrophs expressing sMMO: Detection of enzyme activity and tentative species identification. Environ. Sci. Technol. In review.

Presentations related to this research have been given at the following conferences:

- Subsurface Science Symposium, Inland Northwest Research Alliance, 2003 and 2004 (Erwin and Crawford 2003; Brinkman, et al. 2003; Strap et al. 2004)

- American Society for Microbiology, 2004 and 2005 (Strap et al. 2004, Strap et al. 2005)

- Joint International Symposia for Subsurface Microbiology and Environmental Biogeochemistry, 2005 (Strap et al. 2005, Delwiche et al. 2005)

- $15^{\text {th }}$ Annual Goldschmidt Conference, 2005 (Strap et al. 2005)

- Eighth International In Situ and On-Site Bioremediation Symposium, 2005 (Starr et al. 2005)

- $31^{\text {st }}$ Waste Management Symposium, 2005 (Koelsch et al. 2005)

PI-Colwell has collaborated with Dr. T. Atwater at University of California at Santa Barbara's Education Multimedia Visualization Center (EMVC) funded by the National Science Foundation (http://www.geol.ucsb.edu/projects/emvc/). Through NSF funding the EMVC supported Colwell's travel to UCSB to develop an animation clip that describes the conceptual model whereby microbes cometabolize TCE at TAN. To view a Quicktime preview of the digitized animation or to download the complete version go to: http://www.geol.ucsb.edu/projects/emvc/download/tcedecay.php

\section{Optional Proprietary Information}

None to report.

\section{References}

1. Erwin, D. P., I. K. Erickson, M. E. Delwiche, F. S. Colwell, J. L. Strap, and R. L. Crawford. 2005. Diversity of oxygenase genes from methane- and ammonia-oxidizing bacteria in the Eastern Snake River Plain aquifer. Appl. Environ. Microbiol. 71:20162025.

2. Gilbert, B., I. R. McDonald, R. Finch, G. P. Stafford, A. K. Nielsen, and J. C. Murrell. 2000. Molecular analysis of the pmo (particulate methane monooxygenase) operons from two Type II methanotrophs. Appl. Environ. Microbiol. 66:966-975.

3. Graham, D. W., H. J. Kim, and A. S. Lindner. 2002. Methanotrophic bacteria, p. 1923-1936. In G. Bitton (ed.), Encyclopedia of Environmental Microbiology. John Wiley Press, New York.

4. Kvint, K., L. Nachin, A. Diez, and T. Nystrom. 2003. The bacterial universal stress protein: Function and regulation. Curr. Opin. Microbiol. 6:140-145.

5. Miller, A. R., W. K. Keener, M. E. Watwood, and F. Roberto. 2002. A rapid fluorescence-based assay for detecting soluble methane monooxygenase. Appl. Microbiol. Biotechnol. 58:183-188. 
6. Newby, D. T., D. W. Reed, L. M. Petzke, A. L. Igoe, M. E. Delwiche, F. F. Roberto, J. P. McKinley, M. J. Whiticar, and F. S. Colwell. 2004. Diversity of methanotroph communities in a basalt aquifer. FEMS Microbiol. Ecol. 48:333-344.

7. Nielsen, A. K., K. Gerdes, and J. C. Murrell. 1997. Copper-dependent reciprocal transcriptional regulation of methane monooxygenase genes in Methylococcus capsulatus and Methylosinus trichosporium. Molecular Microbiology 25:399-409.

8. O'Connell, S. P., R. M. Lehman, O. Snoeyenbos-West, V. D. Winston, D. E. Cummings, M. E. Watwood, and F. S. Colwell. 2003. Detection of Euryarchaeota and Crenarchaeota in an oxic basalt aquifer. FEMS Microbiol. Ecol. 44:165-173.

9. Onstott, T. C., T. J. Phelps, T. Kieft, F. S. Colwell, D. L. Balkwill, J. K. Fredrickson, and F. Brockman. 1999. A global perspective on the microbial abundance and activity in the deep subsurface, p. 487-500. In J. Seckbach (ed.), Enigmatic microorganisms and life in extreme environments. Kluwer Academic Publishers, Netherlands.

10. Sorenson, K. S., L. N. Peterson, R. E. Hinchee, and R. L. Ely. 2000. An evaluation of aerobic trichloroethene attenuation using first-order rate estimation. Bioremed. J. 4:337357.

11. Stafford, G. P., J. Scanlan, I. R. McDonald, and J. C. Murrell. 2003. rpoN, mmoR and $\mathrm{mmoG}$, genes involved in regulating the expression of soluble methane monooxygenase in Methylosinus trichosporium OB3b. Microbiology 149:1771-1784.

12. Starr, R. C., M. C. Koelsch, L. N. Peterson, and K. S. Sorenson. 2005. Presented at the Eighth International In Situ and On-Site Bioremediation Symposium, Baltimore, MD.

13. Starr, R. C., M. C. Koeslch, and K. S. Sorenson. 2004. EMSP Annual Report: Coupling of Realistic Rate Estimates with Genomics for Assessing Contaminant Attenuation and Long-Term Plume Containment - Task 4 - Modeling NEW-ID-2004062. North Wind, Inc.

14. Strap, J. L., F. S. Colwell, and R. L. Crawford. 2005. Presented at the 15th Annual Goldschmidt Conference, Moscow, Idaho.

15. Strap, J. L., F. S. Colwell, and R. L. Crawford. Eukaryotic diversity in planktonic and biofilm populations of the Snake River Plain aquifer. Appl. Environ. Microbiol. In review.

16. Strap, J. L., A. L. Torguson, F. S. Colwell, and R. L. Crawford. 2004. Presented at the Annual Meeting American Society for Microbiology.

17. Sturchio, N. C., J. L. Clausen, L. J. Heraty, L. Huang, B. D. Holt, and T. A. Abrajano. 1998. Chlorine isotope investigation of natural attenuation of trichloroethene in an aerobic aquifer. Environmental Science \& Technology 32:3037-3042.

18. Ward, N., O. Larsen, J. Sakwa, L. Bruseth, H. Khouri, A. S. Durkin, G. Dimitrov, L. X. Jiang, D. Scanlan, K. H. Kang, M. Lewis, K. E. Nelson, B. Methe, M. Wu, J. F. Heidelberg, I. T. Paulsen, D. Fouts, J. Ravel, H. Tettelin, Q. H. Ren, T. Read, R. T. DeBoy, R. Seshadri, S. L. Salzberg, H. B. Jensen, N. K. Birkeland, W. C. Nelson, R. J. Dodson, S. H. Grindhaug, I. Holt, I. Eidhammer, I. Jonasen, S. Vanaken, T. Utterback, T. V. Feldblyum, C. M. Fraser, J. R. Lillehaug, and J. A. Eisen. 2004. Genomic insights into methanotrophy: The complete genome sequence of Methylococcus capsulatus (Bath). Plos Biology 2:1616-1628. 